\title{
パキスタンの理学療法と協力隊活動
}

\section{The Present Condition of Physiotherapy and JOCV Activities in Pakistan}

三浦 和 ${ }^{1)}$

\author{
NODOKA MIURA, RPT ${ }^{1)}$ \\ 1) Department of Physical Therapy, International University of Health and Welfare Graduate School: 1-2-25 Odawara city, \\ Kanagawa 250-8588, Japan. TEL +81 465-21-6724
}

Rigakuryoho Kagaku 24(2): 293-296, 2009. Submitted Oct. 24, 2008. Accepted Nov. 5, 2008.

ABSTRACT: I was engaged in physiotherapy at the national institute for handicapped in the Islamic Republic of Pakistan as a member of Japan Overseas Cooperation Volunteer from 2005 to 2007. The aim of the mission was to improve the rehabilitation section of a physiotherapy department. To this aim we tried to improve the quality of physiotherapy for patients and to instruct counterpart and staff, particularly about manual treatments and their evaluation methods. I report on the current situation of physiotherapy in Pakistan and our activities.

Key words: Islamic Republic of Pakistan, physiotherapy, global cooperation

要旨: 2005 年から 2007 年までの 2 年間, 青年海外協力隊員としてパキスタン・イスラム共和国の国立身障者総合病 院で理学療法活動を行った。リハビリ部門強化のため理学療法科の充実を目標に, 患者への理学療法の質の向上 と, カウンターパート及びスタッフの指導, 特に理学療法士 22 名への徒手を使った治療・評価方法の指導を行っ た。主な患者は, 北部大地震の脊髄損傷の入院患者約 90 名であった。パキスタンの理学療法の現状と行ってきた活 動について報告する。

キーワード : パキスタン・イスラム共和国, 理学療法, 国際協力

1) 国際医療福祉大学大学院 保健医療学専攻 : 神奈川県小田原市城山1-2-25（テ250-8588）TEL 0465-21-6724

受付日 2008年10月24日＼cjkstart受理日２008年11月5日 


\section{I.はじめに}

2005 年から 2007 年までの 2 年間, 青年海外協力隊員 としてパキスタン・イスラム共和国で理学療法活動を 行った。派遣目的は, リハビリ部門強化のため理学療 法課の充実を目標に、患者への理学療法の質の向上と, カウンターパート及びスタッフの指導, 特に徒手を使っ た治療・評価方法を指導することであった。パキスタ ンの理学療法の現状と行ってきた活動について報告す る。

\section{II. パキスタン}

\section{1. 概要}

正式名称は，パキスタン・イスラム共和国という。 1947 年イギリスの植民地からインドと分かれ独立した イスラム教国家である。人口は， 1 億 6,250 万人，衛生 面や近親結婚が多いことなどにより，その $10 \%$ 障害 者といわれている。面積は，日本の 2.2 倍であり，4つ の州からなる。言語は, ウルドゥー語・英語が主に使 われている。主要産業は，農業であるが，天候に左右 されやすく安定していない。年間の一人当たりの所得 がUS\$652である発展途上国である。医療の現状は，表 1の通りであり，改善すべき点が多くある。

2005 年 10 月 8 日 北部地域にマグニチュード7.6の大 地震が起こった（図 1)。北部は, 山岳地であり, 不安 定な斜面にレンガを積み重社た家がほとんどであった。 その為, 崩れた家により負傷したものが多く, 救助活 動は困難を極め, 死亡者 74,500 人，負傷者 106,000 人， ホームレス 2 億人の被害が生じた。負傷者の多くは, 骨 折・切断, ついで脊髄損傷・頭部外傷であり, 多くは 首都の病院にヘリコプターで搬送された。

\section{2. 派遣病院}

派遣病院は，国立身障者総合病院という1997年に首 都イスラマバード (パンジャーブ州) に設立された 12 課の総合病院であった。年間患者数 3 万人。手術 650 件。 ベッド 60 床。 2006 年 2 月に震災者のためにユニセフの 寄付で脊髄損傷病棟が設立され, ベッド数が 97 床（男 性 22 名，女性 75 名）増床された。社会福祉部門をもち, 裕福層からの寄付により貧困層一無料で医療を行うよ う図っていたため, 都市の裕福層から遠くの農村から の貧困層まで幅広く治療を求めて患者が訪れている。
表1 日本とパキスタンの医療比較

\begin{tabular}{lcc}
\hline & Japan & Pakistan \\
\hline 平均寿命 (歳) & 82 & 61 \\
乳児死亡率 $/ 1,000$ 人 & 4 & 103 \\
医師数 / 人口 1,000 人 & 2.1 & 0.7 \\
理学療法士数 / 人口 1,000 人 & 0.157 & 0.007 \\
病床数 / 人口 1,000 人中 & 14.3 & 0.7 \\
\hline
\end{tabular}

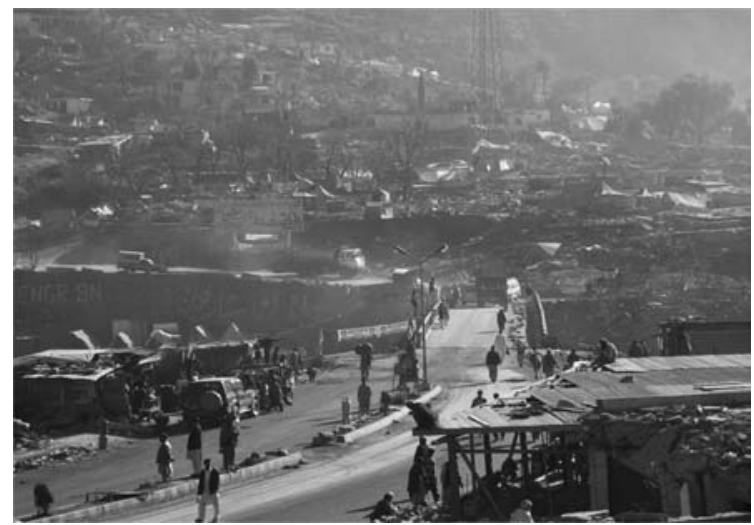

図1 被災地

3. 対象患者

外来では，小児の脳性麻痺・ALS・ギランバレー・筋 ジストロフィーなどの先天性・進行性疾患, 成人の肩 周囲炎・腰痛, 頚部痛・顔面神経麻痺などが訪れてい る。原因不明で, 診断名のついていない患者も多い。入 院では, 骨折, 春髄損傷, 脳性麻痺児の健延長術など がリハビリの対象であった。

\section{4. 理学療法スタッフ}

パキスタン国内の理学療法士（以下, PT）数は, 総 計約 1,200 人であり，女性の割合も少ない。

震災者支援として国立身障者総合病院には，最大 20 名のPT，3人のテクニシャンがパキスタン全土より集 められた。以前から2名のPT（日本に研修経験あり）と 1 名のテクニシャンがおり, 海外 NGO の短期トレーニ ングを受けたケアワーカー達が加わったことで，一時 はパキスタン国内でもつとも理学療法を実施するスタッ フの多い病院となった。

PT は，患者にファーストコンタクトが可能であり， 日本のように「Drの基で」という形ではなく，Drと同 じ立場で患者をみていることから診断する知識も要し た。

外来では, PTは机上での問診・テクニシャンへの指 
表2 理学療法士の比較

\begin{tabular}{|c|c|c|c|c|c|c|c|c|c|}
\hline \multirow[t]{3}{*}{$\begin{array}{l}\text { 国 } \\
\text { Country }\end{array}$} & \multicolumn{4}{|c|}{$\begin{array}{c}\text { 教育 } \\
\text { Education }\end{array}$} & \multicolumn{3}{|c|}{$\begin{array}{c}\text { 実際 } \\
\text { Practice }\end{array}$} & \multicolumn{2}{|c|}{$\begin{array}{l}\text { 側面 } \\
\text { Profile }\end{array}$} \\
\hline & プログラム数 & レベル & 期間 & 年間卒業者 & 規定 & 資格習得 & $\begin{array}{c}\text { Dr を介さず } \\
\text { 診れろ }\end{array}$ & $\begin{array}{c}\text { 理学療法 } \\
\text { 十数 }\end{array}$ & 男女比 \\
\hline & $\begin{array}{l}\text { Number of } \\
\text { Programmes }\end{array}$ & Level & $\begin{array}{c}\text { Length } \\
\text { (yrs) }\end{array}$ & Grads/year & Regulation & Exam/Grad & $\begin{array}{l}\text { Primary } \\
\text { contact }\end{array}$ & PT/Country & $\mathrm{m} / \mathrm{f}$ ratio \\
\hline USA & 181 & & 2,3 & 5000 & Yes & Exam & Yes in 32 states & 108,000 & $1: 02$ \\
\hline Japan & 89 & $\begin{array}{c}\mathrm{PhD}, \mathrm{MA}, \\
\mathrm{BS}, \mathrm{PPT}\end{array}$ & 3,4 & 2800 & Yes & Exam & No & 20,000 & $4: 03$ \\
\hline Pakistan & 学校数 11 & BS, D & 4 & 200 & Yes & Grad & Yes & 1,200 & 7:04 \\
\hline
\end{tabular}

**WCPTより一部抜粋

示が主であり，その指示に従って実際患者に触れ治療 を行うのはテクニシャンであった。整形疾患は, ほぼ 疼痛部への電気温熱治療 (ホットパック, 低周波, TENS, 超音波)のみであり, 徒手的な治療は少ない状況であっ た。その為, 改善せず長い間通ってきている患者や途 中で来なくなる患者が多かった。

小児患者は, 学校などの施設で継続的リ八を行って いることが多く, 外来では月 1 回程度, 診断や自主卜 レーニングの指導, 経過をみることが主であった。

脊髄損傷以外の入院患者は, 金銭面の問題や家族以 外の他人と暮らすことをよく思わない習慣（特に未婚 女性）から，長期間入院することを拒むものが多く，突 然退院していってしまう。そのため, その場限りのも のになってしまい，退院後のADLに直結するようなリ ハビリ計画をたてられないことが多かった。

PT の養成校は, 国内で 9-11校あり, 4 年生の大学卒 業後, 4 年間勉強するものがほとんどであった。教育方 法は, 記憶させることであり, 教科書も図や表がほと んどなく,イメージがつきにくいものであった。理学 療法士スタッフの技術・知識は, 個々により差があっ た。多くは疾患や症状などの質問に対し, 文章ではス ラスラ答えることができるが，個々の患者に応用する こと, 実際の治療に生かすことが難しかった。また, 1 人 1 人の患者に対し,「細かく評価し, そこから問題点 を抽出し、ゴールに向かって治療を行っていく」とい う流れで考えていくことが難しく, その場で, 出てい る現象を改善するという考えで行うものが多かった。 治療によって徐々に患者がよくなるということが体験 できないことが多く, 理学療法士自身, 勉強や仕事一 の意欲がでにくい状況であった。あわせて夏期が長く 高温であることや断食があることなどにより, 患者・ スタッフともに積極的にリハビリを行うのは難しい時 期も多かった。
また，慣習上で，男性は男性を女性は女性を診る， 男女が話すことはまれということもあり，同等の立場 で, 知識の共有やチームアプローチをすることはほと んどなかった。男女で触れ合うことや肌を露出するこ とがよくないこともあり, 解剖学的なことや徒手療法 の技術伝達も十分行えないこともあった。

しかし, 客人を歓待するという文化により, 現地ス タッフは私を暖かく迎えてくれ，また信頼関係ができ てくるにつれ，年下にもかかわらず批判的な話もよく 聞いて改善しょうとしてくれた。患者をよくしたいと いう気持ちはあり, 日によってムラはあったものの「い い」と思ったものは寸ぐ取り入れる,「やる」と決めた ことは, 全スタッフで取り組むという長所もあった。

\section{III. 活動}

\section{1.レクチャー}

基礎知識の向上・実践で知識を生かす，応用力を高 める目的で, 一人一人に課題を設定し, レクチャーを 実施してもらった。文章知識を生かすため,レクチャー で具体的なデモンストレーションも含めるように促し た。臨床での疑問点をどのように解決するかを学習す るため, 足りない知識の抽出, その知識の収集方法か ら、レクチャー実施までのサポートを行った。

\section{2. 評価表}

手を使った治療の一連の流れを理解してもらう目的 で, 評価用紙を作成し, 書き方の指導, 実際の使用を 促し，書いたものもチェックを行った。フィードバッ クは, 応用力をつけるために, 具体例の表示や「考え る」よう質問をしながら行った。

OTという職業の理解, また, ADL といった退院後の 生活を考え, 治療をす寸めていく目的で, ゴールを ADL 
の具体的内容とした。

3. 技術移転

徒手の評価・治療の実践を目的に, 一緒に患者を診, その中で実際やってみせ，その後行ってもらうよう促 し，技術移転を行った。

4. 他職種との連携

Dr，OT，義肢装具士などの他職種との連携を促すた め, 実際, 他職種に協力を求める, 連携が必要な患者 に対しては担当PTがカルテに記入する, そして直接相 談するということを共に行った。また, Dr 回診への参 加も途中より行うこととなった。

5. 患者・家族指導

患者・家族に対して, 普段のリハビリやレクリエー ションを通して, 身体のこと, 介護方法のこと, 肥満 予防のことなどの指導を行っていくように促した(図2)。

\section{IV. 変化点}

以上の活動により, 現地 PTの知識・技術の向上, 自 発的な活動意欲の向上が得られた。

患者に手で触れて評価や治療を行う姿がみられるよ うになった。それに伴い, 患者との会話も増え, 信頼 関係が築けてきているのを感じた。この患者さんのた めに頑張りたいとスタッフの意欲もでてきたように感 じた。

男女での協力, Dr, 義肢装具士, 作業療法士との連 携も取れてきた。

入院中の春髄損傷患者で $79 \%$ を占める $\mathrm{T} 12 \cdot \mathrm{L} 1 \cdot \mathrm{L} 2$ の完全損傷患者を対象に調查を行ったところ, 活動終 了時には, 患者の約 $73 \%$ が機能的ゴールに達すること

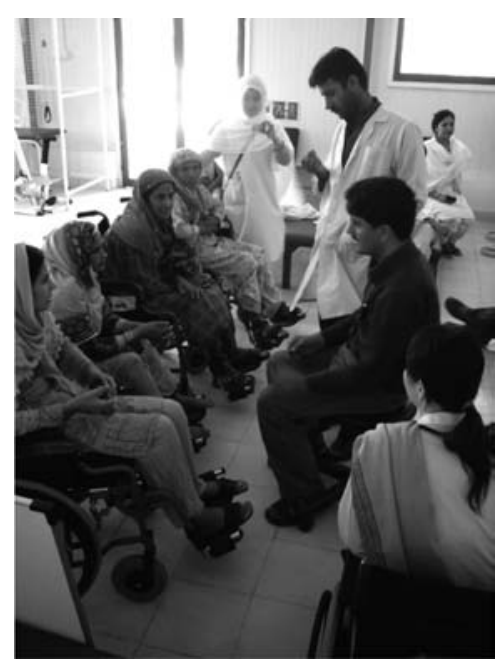

図2 患者指導を行う現地スタッフ

ができた。ゴールに達することのできなかった約 $27 \%$ の患者は，裖瘡などが原因であった。

\section{V. さいごに}

この 2 年間の活動は, 自分にとって大変貴重な体験 となった。多くの人に支えられ，終えることができた と思う。カウンターパートをはじめ, 同僚達, 協力し てくれた上司, 隊員達にこの場をかりて感謝したいと 思う。

\section{参考文献}

1) 古郡恵他 : パキスタン地震の復興支援に参加して, 作業療 法, 2007, 26(1): 83-88.

2) 国際協力機構青年海外協力隊事務局 : クロスロード. 2006.4. 